\title{
Evaluasi Penerapan Sistem Informasi Akuntansi Pada Sistem Pengajuan dan Persetujuan Kredit Pada PT. Bank BRI (Persero) Cabang Muara Enim Unit Rambang Dangku
}

\author{
Pupel Olengga ${ }^{1}$, Andri Eko Putra ${ }^{2}$ \\ ${ }^{1}$ Akutansi, FE Universitas Tridinanti Palembang \\ ${ }^{2}$ Akutansi, FE UPGRI Palembang, andriekop@ounivpgri-palembang.ac.id
}

\begin{abstract}
This study aims to determine the application of accounting information systems to the credit submission and approval system at PT BANK BRI (PERSERO) Branch Muara Enim Rambang Dangku Unit, where management needs to control and develop (SIA) that has been implemented using relevant theories and applied in the Accounting Information System (SIA) which also applies the 5C and 7P Principles to fit the current market and developmental needs of Science and technology. The data used is a flowchart of the credit submission and granting system in 2017. Analysis of data and discussion carried out using qualitative descriptive analysis method that is collecting data in accordance with the actual conditions of the credit submission and approval system implemented by PT BANK BRI (PERSERO) Muara Enim Branch, Dangku Rambang Unit. The results of the discussion can be seen that the lending system implemented by PT BANK BRI (PERSERO) Branch Muara Enim Rambang Dangku Unit has applied the characteristics and elements of the accounting information system (SIA) and applied the precautionary principle, 5C and 7P in granting credit.
\end{abstract}

Keywords: Accounting Information System

\begin{abstract}
ABSTRAK
Penelitian ini bertujuan untuk mengetahui penerapan sistem informasi akuntansi terhadap sistem pengajuan dan persetujuan kredit pada PT BANK BRI (PERSERO) Cabang Muara Enim Unit Rambang Dangku, dimana pihak manajemen perlu untuk mengontrol dan mengembangkan (SIA) yang telah dijalankan dengan menggunakan teori-teori yang relevan dan diterapkan di dalam Sistem Informasi Akuntansi (SIA) yang juga menerapkan Prinsip 5C dan 7P agar sesuai dengan kebutuhan pasar dan perkembangan IImu Pengetahuan dan teknologi yang berlaku saat ini. Data yang digunakan merupakan bagan alir (flowchart) sistem pengajuan dan pemberian kredit pada tahun 2017. Analisis data dan pembahasan yang dilakukan dengan menggunakan metode analisis deskriptif kualitatif yaitu mengumpulkan data sesuai dengan keadaan yang sebenarnya atas sistem pengajuan dan persetujuan kredit yang telah dilaksanakan oleh PT BANK BRI (PERSERO) Cabang Muara Enim Unit Rambang Dangku. Hasil pembahasan dapat diketahui bahwa sistem pemberian kredit yang sudah dilaksanakan oleh PT BANK BRI (PERSERO) Cabang Muara Enim Unit Rambang Dangku sudah menerapkan karakteristik dan unsur-unsur sistem informasi akuntansi (SIA) dan menerapkan prinsip kehati-hatian yaitu 5C dan 7P dalam pemberian kredit.
\end{abstract}

Kata Kunci : Sistem Informasi Akuntansi

\section{A. Pendahuluan}

Dewasa ini perbankan merupakan salah satu unsur pengembangan perekonomian juga sebagai lembaga yang berkewajiban turut serta memperlancar arus kegiatan dibidang ekonomi dan moneter. Sebagai suatu perusahaan, bank mempunyai tujuan-tujuan untuk memperoleh keuntungan, keuntungan tersebut 
sebagian besar diperoleh dari aktivitas kredit. Perkreditan sebagai kegiatan pokok perbankan, merupakan sarana penyaluran dana bank yang ditanamkan oleh pihak ketiga dengan persetujuan tertentu dalam bentuk besarnya pokok pinjamman yang diberikan, tingkat bunga pertahun, dan jangka waktu pelunasan serta cara pelunasannya. Pengguna kredit tidak selamanya seperti yang diharapkan, terbatasnya dana yang tersedia dibandingkan dengan jumlah permintaan kredit merupakan masalah yang dihadapi oleh perbankan dewasa ini. Masalah lain yang sering terjadi kredit yang bermasalah antara lain kredit macet. Hal ini tentu saja akan mengakibatkan kerugian bank. Oleh karena itu manajer bank harus mengadakan seleksi terhadap permohonan kredit. Hal-hal tersebut dapat dihindari dengan sistem informasi akuntansi yang memadai dalam pemberian kredit diharapkan dapat menjamin bahwa dalam pelakasanaan pemberian kredit dapat terkendali dan mampu mencegah terjadinya kesalahan yang dapat merugikan bank dan dapat mencegah terjadinya pemberian kredit yang tidak sehat. Bank juga memerlukan adanya suatu pengendalian guna tercapainya tujuan perusahaan secara menyeluruh. Pengendalian ini bersifat pengendalian preventif dan pengendalian represif. Untuk tercapainya tujuan tersebut bank memerlukan sistem informasi yang baik sehingga kredit tersebut tidak bermasalah, dalam hal ini bank harus hati-hati dalam memberikan kredit kepada nasabahnya dengan cara memperhatikan prinsip-prinsip kredit yaitu:5C (character, capacity, capital, collateral, dan condition of economy), dan 7 P ( personality, party, purpose, prospect, payment, prfitability, dan protection) serta menerapkan sistem informasi akuntansi yang memadai. Dengan adanya sistem informasi akuntansi yang memadai akan diperoleh informasi yang relevan. Informasi yang ada dalam suatu kegiatan usaha sangat penting, guna mendukung produktivitas serta daya saing kegiatan usaha tersebut.

Penerepan sistem informasi akuntansi dimasudkan agar dapat membantu para manajemen dalam pengambilan keputusan terutama dalam hal ini yaitu kebijakan pemberian kredit kepada calon debitur. Dalam menjalankan sistem informasi akuntansi, pada proses pengajuan dan persetujuan kredit harus efektif dan efisien karena akan mempengaruhi keberhasilan suatu perusahaan dalam menjalankan kebijakan pemberian kredit. PT BANK BRI (PERSERO) Cabang Muara Enim Unit Rambang Dangku merupakan salah satu bank yang menerapkan sistem informasi akuntansi sebagai alat pertimbangan pengambilan keputusan terutama dalam prosedur pemberian kredit kepada nasabah. Bank BRI (Persero) Cabang Muara Enim Unit Rambang Dangku menerapkan prosedur pemberian kredit berdasarkan peraturan dari Bank Indonesia.

Prosedur Pemberian kredit dimulai dari permohonan calon debitur. Dalam hal ini kegiatan tersebut hanya melibatkan satu bagian yang ada dalam perusahaan yaitu bagian perkreditan. Bank berpandangan bahwa sistem informasi akuntansi yang diberlakukan di perusahaan sangat berguna dalam melaksanakan aktivitas perusahaan serta bermanfaat bagi manajemen dalam pengambilan keputusan pemberian kredit pada calon debitur atau nasabah. Penerapan sistem informasi akuntansi perkreditan pada PT BANK BRI (PERSERO) Cabang Muara Enim Unit Rambang Dangku sesuai dengan karakteristik sistem informasi akuntansi (usefullness, economy, reability, customer service, capacity, simplicity, dan flexibility) serta unsur- unsur sistem informasi akuntansi (manusia, alat, dan metode). Mengingat pentingnya sistem informasi akuntansi sebagai salah satu alat pertimbangan pengambilan keputusan bagi pihak manajemen PT BANK BRI (PERSERO) Cabang Muara Enim Unit Rambang Dangku telah menerapkan 
sistem informasi akuntansi yang memadai dalam memberikan kebijakan kredit, termasuk dalam proses pengajuan dan persetujuan kredit. Sistem informasi akuntansi dalam kebijakan pemberian kredit akan menghasilkan informasi yang berguna bagi manajemen dalam menilai kelayakan pemberian kredit kepada calon debitur. Penyeleksi terhadap calon debitur pun harus dilakukan untuk menghindari permasalahan yang akan terjadi. Seperti adanya calon debitur yang tidak sesuai dengan persyaratan yang telah ditetapkan oleh bank serta adanya calon debitur yang tidak mentaati prosedur dan ketentuan yang telah diberlakukan oleh bank. Permaslahan umum lain yang terkadang juga terjadi pada bank adalah adanya debitur yang melakukan permohonan kredit namun debitur tersebut masih tercatat sebagai peminjam kredit di bank lain. Jika dilihat dari pihak bank, kadang-kadang pihak bank yang melakukan keteledoran dalam mentaati peraturan pemberian kredit yang telah ditetapkan oleh bank, kurangnya pengawasan terhadap debitur, serta pihak analis kredit kurang teliti dalam mengecek kebenaran dan keaslian dokumen calon debitur.

Dengan adanya sistem informasi akuntansi yang memadai dalam proses pemberian kredit diharapkan dapat menjamin bahwa pelaksanaan pemberian kredit dapat terkendali dan mampu mencegah pemberian kredit dengan cara tidak sehat. Sejauh ini sistem informasi akuntansi pada PT. Bank BRI (Persero) Cabang Muara Enim Unit Rambang Dangku telah memadai dan sudah berjalan dengan baik, namun dalam hal ini peneliti ingin mengetahui bagaiman penerapan sistem informasi akuntansi sehubungan dengan sistem pengajuan dan persetujuan kredit.

\section{B. Rumusan Masalah}

Rumusan masalah yang menjadi fokus dalam penelitian ini adalah : Bagaimana Penerapan Sistem Informasi Akuntansi Atas Pengajuan dan Persetujuan Kredit Pada PT.Bank BRI (Persero) Cabang Muara Enim Unit Rambang Dangku?

\section{Metode Penelitian}

Menurut Sadarmayanti dan Hidayat (2011:25) Metode penelitian adalah pembahasan mengenai konsep teoritik berbagai metoda, kelebihan dan kelemhannya, yang dalam karya ilmiah dilanjutkan dengan pemilihan metoda yang digunakan, Metode penelitian yang digunakan adalah deskriptif yaitu penelitian yaitu dilakukan untuk mengevaluasi sistem informasi akuntansi pada sistem pengajuan dan persetujuan kredit.

\section{Populasi dan Sampel \\ 1) Populasi}

Menurut Sugiyono (2017:80), populasi adalah wilayah generalisasi yang terdiri atas : objek/subjek yang menpunyai kualitas dan karakteristik tertentu yang diterapkan oleh peneliti untuk dipelajari dan kemudian ditarik kesimpulannya.

Populasi dalam penelitian ini adalah sistem informasi akuntansi atas sistem pengajuan dan persetujuan kredit .

\section{2) Sampel}

Menurut Sugiyono (2017:81), sampel adalah bagian dari jumlah dan karakteristik yang dimiliki oleh populasi tersebut. Sampel dalam penelitian ini adalah 
sistem pengajuan dan persetujuan kredit pada PT. Bank Bri (Persero) Cabang Muara Enim Unit Rambang Dangku tahun 2017.

\section{E. Teknik Pengumupulan Data}

Adapun Metode Pengumpulan Data penelitian ini menggunakan beberapa cara atau metode-metode yaitu :

\section{Studi Pustaka}

Merupakan data yang diambil dari literatur tulisan, gambar, jurnal, dan diktatdiktat kuliah, sehingga dapat digunakan sebagai pegangan dalam membahas permasalahan dalam skripsi ini.

\section{Dokumentasi}

Merupakan pengumpulan data sekunder melalui dokumen-dokumen yang dimiliki dan merupakan kejadian di masa lalu atau dicetak, berupa catatan, surat, buku harian dan bagan alir (flowchart).

a. gambaran umum perusahaan

b. sturktur organisasi perusahaan dan pengawasan tugas

c. penerapan sistem informasi akuntansi

d. sistem pengajuan dan persetujuan kredit

\section{F. Teknik Analisis Data}

Teknik analisis data yang digunakan dalam penelitian ini adalah analisis deskriptif kualitatif dengan pendekatan studi kasus, yaitu metode yang berusaha untuk memberikan gambaran secara sistematis dan akurat mengenai fakta, sifat dari hubungan antara fenomena yang diteliti pada suatu perusahaan. gambaran yang sistematis dan akurat yang diperoleh dengan mengumpulkan, mengklasifikasi, menganalisis data sehingga akan memberikan hasil yang konkrit akan permasalahan dan kemudian dilaksanakan analisis sehingga dapat ditarik kesimpulan. Dalam hal ini dipilih salah satu bagian dalam PT.Bank BRI (Persero) Cabang Muara Enim Unit Rambang Dangku kemudian dikaji secara rinci dan mendalam berdasarkan teori yang dipelajari sebelumnya. berdasarkan objek penelitian yang sudah dikemukakan diatas, pengumpulan data dilakukan secara observasi, dan studi terhadap dokumen bagan alir (flowchart) dan catatan pada PT Bank BRI (persero) cabang muara enim unit rambang dangku. data yang diperoleh kemudian disusun, diolah, dan selanjutnya dilakukan analisis sehingga menghasilkan suatu kesimpulan.

\section{G. Hasil Penelitian}

1) Pelaksanaan Sistem Informasi Akuntansi Dalam Pemberian Kredit

PT. Bank BRI (Persero) Cabang Muara Enim Unit Rambang Dangku merupakan salah satu bank yang dalam kegiatan operasionalnya sehari-harinya sangat memperhatikan sistem informasi akuntansi yang berlaku, terlebih pada pelaksanaan sistem informasi akuntansi yang dijalankan oleh perusahaan. PT. Bank BRI (Persero) Cabang Muara Enim Unit Rambang Dangku mempunyai pandangan bahwa fungsi sistem informasi akuntansi yang diberlakukan di perusahaan sangat membantu pimpinan perusahaan dalam menjalankan aktivitas perusahaan dan dimanfaatkan manajemen sebagai pengambil keputusan dalam aktivitas pemberian kredit pada nasabah. 
Sistem informasi akuntansi yang diterapkan pada PT. Bank BRI (Persero) Cabang Muara Enim Unit Rambang Danku dilakukan dengan manual dan komputerisasi yang bertaraf sesuai keadaan serta perkembangan perusahaa.

Sistem informasi akuntansi pemberian kredit yang dilakukan PT. Bank BRI (Persero) Cabang Muara Enim Unit Rambang Dangku tidak terlepas dari karakteristik dan unsur-unsur sistem informasi akuntansi yang ada:

\section{a) Karakteristik Sistem Informasi Akuntansi}

1. Kegunaan(Usefullness)

Dengan penerapan Sistem informasi akuntansi dalam pemberian kredit pada PT.Bank BRI (Persero) Cabang Muara Enim Unit Rambang Dangku dapat menghasilkan informasi yang berupa pemberian kredit sesuai dengan kebutuhan (relevan) dan tepat waktu, sehingga berguna bagi manajemen sebagai dasar pengambilan keputusan.

2. Ekonomi(Economy)

Seluruh komponen dari sistem harus dapat memberikan sumbangan yang besar biaya yang dikeluarkan.

3. Andal(Reability)

Dalam sistem pemberian kreditpada PT.Bank BRI (Persero) Cabang Muara Enim Unit Rambang Dangku selalu memperhatikan kelengkapan persyaratan berkas kredit dan juga telah menerapkan analisis yang baik dalam menganalisis persyartan dokumen kredit dan lantar belakang calon debitur untuk menghindari terjadinya masalah pada masa yang akan datang oleh karena itu sistem harus dapat diandalkan, informasi yang dihasilkan melalui sistem harus mempunyai ketelitian yang tinggi dan sistem itu sendiri harus mampu beroperasi secara efektif.

4. Pelayanan(Customer Service)

Staff customer service memberikan suatu layanan yang baik dan efisien kepada para debitur.

5. Kapasitas (Capacity)

Kapasitas dari suatu sistem cukup memadai yang dimiliki sistem serta keandalan, ketelitian, dan kebenaran informasi dan dokumen lebih terjamin dalam menghadapi operasi pada kapasitas penuh seperti halnya pada operasi berjalan normal.

6. Sederhana (Simplicity)

Sistem pemberian kredit pada PT.Bank BRI (Persero) Cabang Muara Enim Unit Rambang Dangku cukup sederhana sehingga semua struktur dan operasinya dapat dimengerti serta prosedurnya dan dapat diikuti dengan mudah.

7. Sederhana (Flexibility)Sistem harus luwes dalam menampung dan menghadapi semua perubahan yang terjadi dari dalam maupun luar perusahaan.

\section{b) Unsur-Unsur Sistem Informasi Akuntansi}

1. Manusia

Manusia merupakan salah satu unsur sistem informasi akuntansi yang berperan didalam pelaksanaan sistem informasi akuntansi, menetukan apakah suatu sistem itu dapat dilaksanakan dengan sebaik-baiknya serta berperan tidaknya sistem tersebut dalam proses pengambilan keputusan. 
2. Alat

Alat merupakan dari sistem informasi akuntansi, mulai digunakan pada saat terjadinya transaksi pencatatan transaksi. Sampai dengan dihasilkannya laporan. Alat yang dimaksud dapat berbentuk alat-alat sederhana seperti formulir, catatan, laporan sampai alat teknologi seperti komputer.

a. Formulir

Merupakan alat dalam sistem informasi akuntansi yang digunakan untuk mencatat bukti-bukti transaksi dalam buku jurnal dan buku besar.

Dalam merancang suatu formulir prinsip-prinsip berikut ini harus diperhatikan.

b. Menggunakan Tembusan

Untuk memenuhi beberapa tujuan sekaligus dan untuk mengurangi pekerjaan klerikal, yang dapat dengan sekali pekerjaan klerikal, bebrapa tujuan dapat tercapai.

c. Pencantuman Nomor Urut Tercetak

Nomor urut tercetak digunakan untuk mengawasi pemakaian formulir dan untuk mengidentifikasi transaksi bisnis. Nomor urut tercetak ini akan dicantumkan didalam catatan akuntansi, sehingga memudahkan pencarian kembali dokumen yang dicatat dalam pencatatan tersebut.

d. Rancangan Formulir Yang Sederhana Dan Ringkas

Formulir yang dirancang sederhana dan ringkas akan menghindarkan perekaman data yang tidak perlu sehingga akan membantu pencatatan kedalam jurnal dan pembantu.

e. Cantumkan Nama Dan Alamat Perusahaan

Formulir untuk antarbagian didalam perusahaan tidak perlu memuat nama dan alamat perusahaan. Namun formulir yang dikirim keluar perusahaan nama, alamat dan logo perusahaan perlu dicantumkan untuk memudahkan pengidentifikasian asal formulir tersebut bagi perusahaan penerimaan.

f. Nama Formulir

Nama formulir biasanya untuk menggambarkan fungsi formulir tersebut dan untuk memudahkan pengidentifikasian formulir tersebut.

g. Catatan

Didalam sistem informasi akuntansi terdapat beberapa buku yang digunakan untuk melakukan pencatatan transaksi. Buku-buku dan catatan tersebut adalah:

a. Jurnal, merupakan buku catatan pertama (books of original entry).

b. Buku besar, merupakan buku catatan akhir (books of final entry).

h. Laporan

Informasi yang dihasilkan berupa laporan-laporan yang diperoleh dari hasil pengolahan data, semua data yang diperoleh perusahaan kredit sesuai dengan kebutuhan manajer agar dapat menghasilkan laporan yang baik. Untuk menghasilkan laporan yang baik maka dibutuhkan dokumen yang informasi lengkap

i. Komputer

Komputer telah menjadi alat yang tidak dapat dihindarkan dalam sistem informasi akuntansi sebagai besar perusahaan. Hal ini ditandai dengan semakin banyaknya perusahaan, khususnya perusahaan menengah dan besar, yang telah memasang perangkat komputer didalam perusahaanya yang tidak hanya mengolah data menjadi informasi, seperti penggunaan komputer dalam sistem komunikasi, jaringan digital dan lain-lain. 


\section{Metode Sistem Dan Prosedur}

Metode ini adalah sistem dan prosedur merupakan gambaran yang mencakup seluruh jalannya kegiatan, mulai dari saat dimulainya aktivitas sampai dengan adanya sistem dan prosedur diharapkan suatu kegiatan operasi dapat dilaksanakan dengan efektif, efisien, dan ekonomi.

\section{2) Pelaksanaan Prosedur Pemberian Kredit Pada Pada PT.Bank BRI (Persero) Cabang Muara Enim Unit Rambang Dangku}

Setelah memahami prinsip dasar pemberian kredit, para kreditur melakukan prosedur pemberian kredit yaitu tahap pertama dalam proses pemberian kredit adalah pengajuan permohonan kredit oleh calon debitur. Permohonan ini bisa diajuhkan secara tertulis tetapi dalam prakteknya lebih banyak dilakukan secara lisan. Pada tahapaan ini bank (account officer) berkenalan dengan calon debitur, terutama apabila calon debitur tersebut bukan merupakan nasabah bank. Pada kontak awal ini masing-masing pihak saling berkenalan. Calon nasabah mengemukakan maksutnya secara sekilas, apabila calon debitur sama sekali baru bagi bank, debitur harus menceritakan secara singkat usahanya (apabila debitur seorang karyawan). Pada saat itu juga calon debitur mengajuhkan jumlah kredit yang diinginkan dari bank serta tujuannya. Prosedur pemberian kredit berdasarkan debitur dan kreditur.

$>\quad$ Calon Debitur

Mengajukan surat permohonan/ mengisi formulir aplikasi berikut kelengkapannya dengan lampiran sebagai berikut:

a. Foto copy identitas diri (KTP, SIM, atau PASPOR)

b. Foto copy akte nikah (bagi yang sudah menikah)

c. Foto copy kartu keluarga (KK)

d. Foto copy rekening koran / rekening giro atau copy buku tabungan di bank manapun antara enam hingga tiga bulan terakhir

e. Foto copy slip gaji dan keterangan bekerja dari perusahaan

$>\quad$ Pinjaman / Kredit Badan Usaha

a. Foto copy identitas perusahaan (direksi dan komisarisnya)

b. Foto copy SIUP (Surat Izin Usaha Perdagangan)

c. NPWP (Nomor Pokok Wajib Pajak)

d. Foto copy TDP (Tanda Daftar Perusahaan)

e. Akta Pendirian (awal beserta perusahaannya)

f. Foto copy agunan (SHM,BPKB,dll)

g. Foto copy IMB (Izin Mendirikan Bangunan)

$>$ Bank

a. Terima surat permohonan register.

b. Cek list kelengkapan dokumen.

c. Cek daftar Hitam BI jika termasuk-ditolak, jika tidak diproses.

d. Wawancara secara on the spot.

e. Buat surat penolakan jika pejabat pemutus mengatakan tidak layak.

f. Bila usaha calon debitur visible (bisa dilihat) bank akan memproses.

g. Melakukan analisis ekonomi, pengumpulan dan pengecekan data.

h. Membuat memorandum analisis yuridis.

i. Selanjutnya bank melakukan penilaian jaminan melihat kemungkinan pemasaran. 
j. Proposal kredit yang lengkap diserahkan ke pejabat pemutus untuk mendapat putusan setelah diputus. Bank akan buat surat pemberitahuan dan didalamnya memuat syarat dan ketentuan yang harus dipenuhi oleh calon debitur.

Apabila permohonan kredit dinilai layak maka pihak bank dalam hal ini petugas Mantri akan mengadakan pengumpulan data lapangan baik menyangkut data pribadi maupun reputasi dan hal-hal lain yang berhubungan dengan bisnis calon debitur:

a. Debitur / pinjaman berupa badan usaha antara lain:

- Identitas calon debitur

- Bidang usaha, lokasi dan lama usaha.

- Daftar supplier (seperti nama dan alamat) untuk usaha tersebut dan sistem pembelian apakah pembelian dilakukan secara tunai (cash) atau secara kredit. Apabila pembelian dilakukan dengan sistem kredit, bagaimana kebijakan kredit yang diterapkan (sistem pembayarannya).

- Daftar langganan (seperti nama dan alamat ) serta sistem penjualan yang diterapkan calon debitur, apakah penjualan secara tunai atau dilakukan secara kredit. Apabila secara kredit bagaimana sistem pembayarannya.

- Data keuangan seperti omzet, laba, dan Iain-lain. Apabila ada, Mantri akan meminta laporan keuangan calon debitur (baik yang telah diaudit maupun yang belum) meliputi laporan rugi laba dan neraca untuk memperoleh gambaran mengenai struktur keuangan calon debitur.

- Apabila ada, Mantri juga akan meminta fotokopi rekening koran beberapa bulan terakhir. Apabila calon debitur memiliki fasilitas kredit di bank lain, ia juga akan mencari tahu tentang kondisi kredit tersebut seperti jenis kredit, jumlah fasilitas, suku bunga, dan kondisi lainnya.

- Untuk badan hukum (PT, CV) juga dikumpulan data mengenai manajemen perusahaan selain akte pendirian perusahaan dan perubahan-perubahannya.

b. Debitur / peminjam berupa individu antara lain:

- Apabila usaha yang akan dibiayai adalah usaha baru, Mantri perlu mengetahui rencana-rencana kerja calon debitur untuk usaha barunya seperti manajemen, rencana pemasarannya, rencana produksi dan lain-lain.

- Untuk calon debitur yang merupakan karyawan murni tentu saja yang dikumpulkan tidak akan sekompleks peminjam berupa badan usaha, biasanya untuk karyawan data yang dikumpulkan adalah:

1. Nama perusahaan tempat debitur bekerja, lamanya debitur bergabung dengan perusahaan tersebut, serta jabatan calon debitur. Seringkali calon debitur diminta daftar riwayat pekerjaannya.

2. Besarnya penghasilan per bulan yang biasanya dibuktikan dengan surat keterangan gaji.

3. Sumber dan jumlah penghasilan tambahan apabila ada.

4. Jumlah tanggapan seperti jumlah anak.

5. Mantri juga perlu mengetahui apakah keryawan tersebut memiliki kredit yang lain. Hal ini perlu diketahui karena pada umumnya kredit yang diminta karyawan adalah kredit konsumsi (seperti KPR) sehingga jika debitur memiliki kredit di tempat lain (yang dilakukan secara cicilan), hal tersebut langsung mempengaruhi kemampuan mengangsur kredit.

Tahap yang paling menentukan dalam analisis dan pengambilan keputusan pemberian kredit adalah penentuan layak atau tidak permohonan kredit calon 
debitur. Di sisi pihak bank, khususnya Mantri dituntut objektif dan konsisten hasil analisa dengan berpegang pada prinsip-prinsip kelayakan kredit. Dalam dunia prinsip analisis kredit dikenal dengan konsep $5 \mathrm{C}$ yaitu:

1. Watak (Character)

Mantri harus mencari tahu sifat-sifat dari calon debitur. Hal ini terutama berhubungan dengan kemauan dari calon debitur untuk melakukan kewajibankewajibannya. Analisis ini lebih cenderung merupakan analisa kualitatif yang tidak terbaca dengan angka-angka yang disajikan. Untuk memperoleh informasi tersebut seorang Mantri dapat melakukannya dengan mencari informasi melalui:

- Sesama mantri baik dari bank yang sama maupun bank yang berbeda

- Nasabah bank yang memiliki bidang usaha yang sama dengan calon debitur

- Supplier atau mitra dagang dari pemohon

2. Kapasitas (Capacity)

Pada analisa ini bank berusaha mengetahui kemampuan manajemen mengoperasikan perusahaannya sehingga dapat memenuhi kewajibannya terhadap bank secara rutin dan pada saat jatuh tempo. Sebagian aspek ini dapat dibaca dari laporan keuangan yang disediakan perusahaan seperti kondisi likuiditas (kemampuan perusahaan dalam memenuhi kebutuhan jangka pendek maupun solvabilitas atau kebutuhan jangka panjaang yang jatuh tempo), rentabilitas (kemampuan perusahaan untuk mencapai laba dari hasil operasinya), dan aspek keuangan lain yang merupakan refleksi kemampuan manajemen. Di samping angka-angka, aspek kapasitas ini juga harus dianalisis secara kualitatif, yaitu kemampuan manajemen meliputi umur, pengalaman di bidangnya, dan pendidikan. Untuk mengukur kemampuan ini maka sering kali Mantri meminta daftar riwayat hidup dari calon debitur atau manajemennya apabila calon debitur adalah perusahaan.

3. Modal (Capital)

Analisis aspek capital ini meliputi struktur modal yang disetor, cadangancadangan dan laba yang ditahan dalam struktur keuangan perusahaan. Besarnya modal sendiri ini menunjukkan tingkat resiko yang akan ditanggung oleh debitur dalam pembiayaan suatu proyek.

4. Kondisi (Condition)

Analisis terhadap aspek ini meliputi analisis terhadap variabel ekonomi makro yang mencakup perusahaan baik variabel regional, nasional, maupun internasional. Variabel yang diperhatikan terutama adalah variabel ekonomi (walaupun tidak terlepas juga bank perlu memperhatikan variabel lainnya seperti kondisi politik, perundang-undangan, dan lain-lain)

5. Jaminan (Collecteral)

Penilaian ini meliputi penilaian terhadap jaminan yang diberikan debitur sehingga pengaman kredit yang diberikan bank. Penilaian tersebut meliputi kecendrungan nilai jaminan di masa depan dan tingkat kemudian mengkonversikannya menjadi uang tunai (marketability).

Selain konsep/ prinsip 5C tersebut di atas dalam prakteknya bank juga seringkali menetapkan dasar penilaian lain yang sering disebut dengan penilaian 7P yaitu: 
1. Kepribadian (Personality)

Bank mencari data tentang kepribadian calon debitur seperti riwayat hidupnya (kelahiran, pendidikan, pengalaman, usaha/ pekerjaan, dan sebagainya), hobi, keadaan keluarga (istri, anak), social standing (pergaulan dalam masyarakat serta bagaimana pendapat masyarakat tentang diri si peminjam), serta hal-hal lain yang erat hubungannya dengan kepribadian si peminjam.

2. Tujuan (Purpose)

Mencari data tentang tujuan atau keperluan penggunaan kredit. Apakah akan digunakannya untuk berdagang, atau untuk membeli rumah atau untuk tujuan lainnya. Selain ini apakah tujuan penggunaan kredit itu sesuai dengan Line Of Bussiness kredit yang bersangkutan.

3. Prospek (Prospect)

Yang dimaksud dengan prospek adalah harapan masa depan dari bidang usaha atau kegiatan usaha si peminjam. Ini dapat diketahui dari perkembangan usaha peminjam selama beberapa bulan / tahun, perkembangan keadaan ekonomi perdagangan, keadaan ekonomi / perdagangan sektor usaha si peminjam, kekuatan keuangan perusahaan yang dibuat dari earning power(kekuatan pendapatan / kekuatan) masa lalu dan perkiraan masa mendatang.

4. Pembayaran (Payment)

Mengtahui bagaimana perkiraan pembayaran kembali pinjaman yang akan diberikan. Hal ini dapat diperoleh dari perhitungan tentang prospek, kelancaran penjualan dan pendapatan sehingga dapat diperkirakan kemampuan pengembalian pinjaman ditinjau dari waktu serta jumlah pengambilannya.

5. Profitabilitas (Profitability)

Menilai berapa tingkat keuntungan yang akan diraih calon debitur, bagaimana polanya, apakah makin lama makin besar atau sebaliknya.

6. Perlindungan (Protecion)

Menilai bagaimana calon debitur melindungi usaha dan mendapatkan perlindungan usaha. Apakah dalam bentuk jaminan barang, orang atau asuransi.

7. Kelompok (Party)

Bertujuan mengklasifikasi calon debitur berdasarkan modal, loyalitas dan karakternya. Pengklasifikasian ini akan menentukan perlakuan bank dalam hal pemberian fasilitas.

- Komputer dan Teknologi informasi

Setelah diterima data mengenai para calon debitur, maka aliran informasi yang digunakan adalah flowchart merupakan sistem yang mencatat dan meringkas transaksi kredit yang terjadi pada jenjangorganisasi paling bawah, yang dimasukkan kedalam komputer kemudian secara terstruktur melaporkan informasi kepada manajemen puncak dan ditetapkan berssama-sama dengan sistem penganggaran kinerja yang sering disebut dengan sistem akuntansi pertanggung jawaban (responsibility accounting system). Laporan yang dihasilkan berisi perbandingan antara realisasi kegiatan dan tujuan kinerja (terget) yang telah ditetapkan dalam sistem penganggaran. Atas dasar laporan ini. BRI mengevaluasi kinerja setiap bagian yang bertanggung jawab, guna mengetahui apakah ada penyimpangan terhadap tujuan yang telah ditetapkan sebelumnya. 
Pada PT. Bank Rakyat Indonesia (Persero) Tbk Cabang Muara Enim Unit Rambang Dangku. Informasi data yang masuk menggunakan terminal on-linebatch processing, komputer menangkap data secara elektronik, mengedit akurasi dan kelengkapan, setelah itu menyimpanannya untuk diproses lebih lanjut dimasa mendatang setelah mencapai kesepakatan kredit.

\section{3) Teknik Dokumentasi Sistem Informasi Akuntansi Dalam Prosedur Pengajuan Dan Persetujuan Kredit}

Setelah data masuk kedalam komputer, tahap yang paling penting dalam perancangan instrumen pencatatan adalah perancangan bagan rekening. Bagan rekening yang telah diberi nomor bukan saja mempermudah penyusunan laporan keuangan, namun juga mempengaruhi proses persetujuan kredit calon debitur.

Teknik sistem merupakan alat yang digunakan dalam analisis, desain dan dokumentasi serta memahami kalian antar-subsistem. Teknik sistem ini biasanya berupa diagram. Flowchart merupakan teknik sistem yang paling sering digunakan, yang merupakan dengan simbol guna menunjukan arus data dan tahapan operasi dalam sebuah sistem simbol pada bagan aliran merupakan simbol yang direkomendasikan oleh The American Nasional Standar Institute (ANSI). Dalam sistem teknik dan dokumentasi pemberian kredit prosedur dilihat dari sistem bagan alir (Flowchart) yaitu:

\section{Pengajuan Permohonan Kredit Dan Persetujuan Kredit Permohonan Kredit}

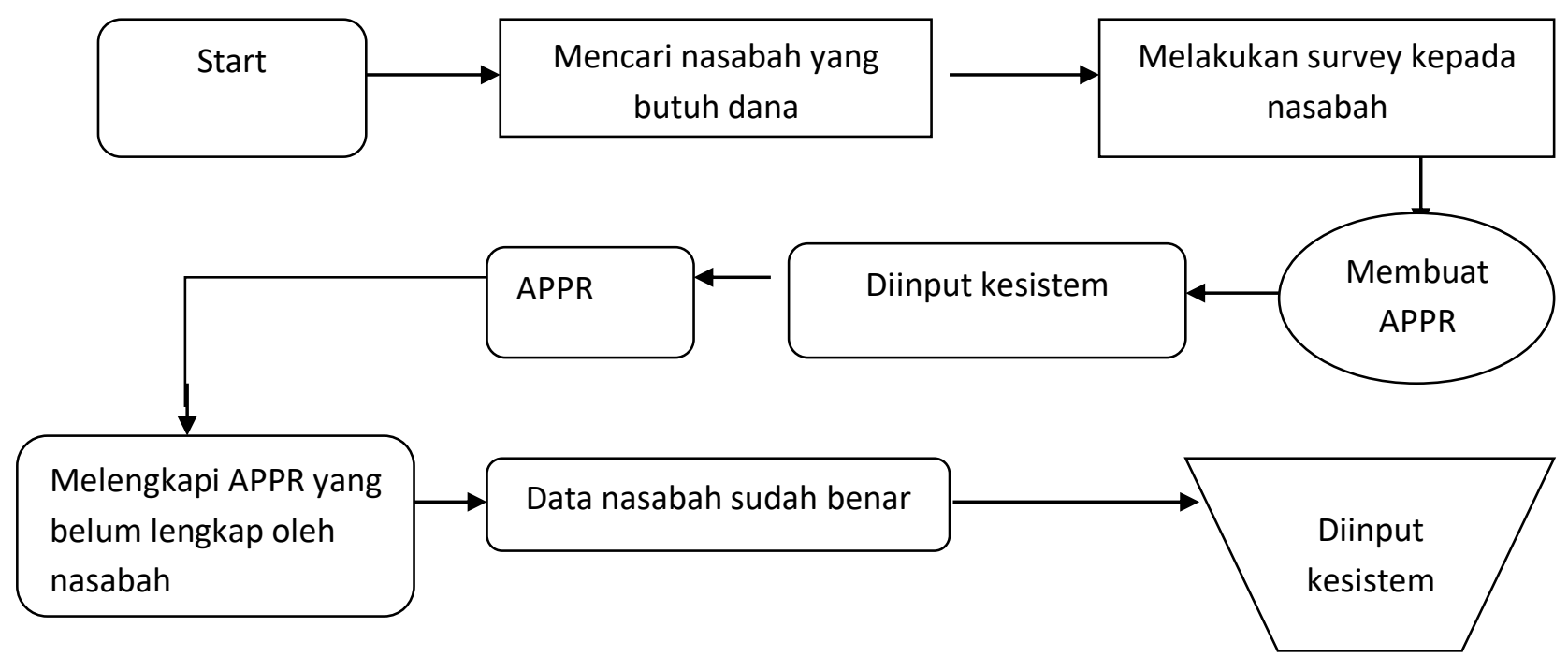

Sumber: PT. Bank Rakyat Indonesia (Persero) Tbk. Cabang Muara Enim Unit Rambang dangku 2017 


\section{Prosedur Pengecekan Permohonan Kredit}

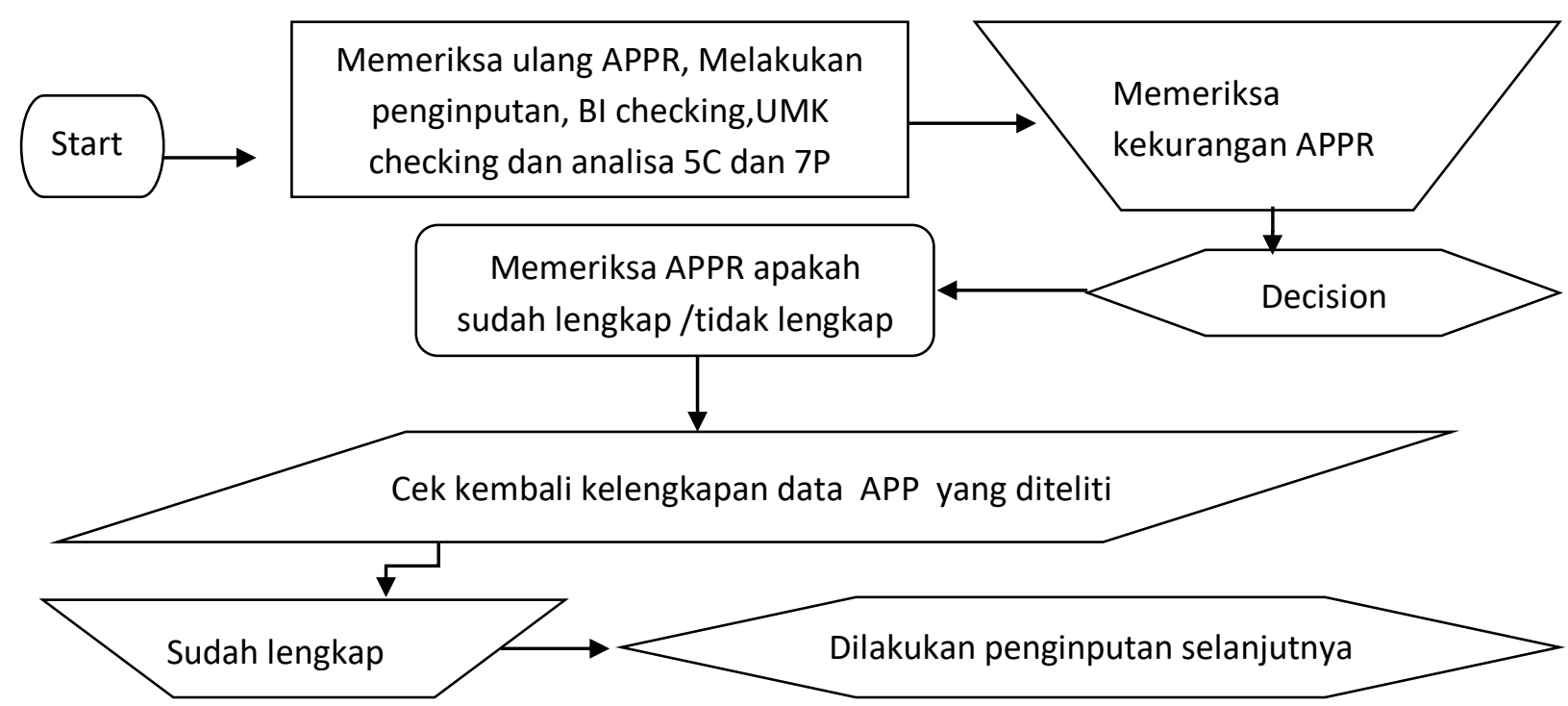

Sumber: PT. Bank Rakyat Indonesia (Persero) Tbk. Cabang Muara Enim Unit Rambang dangku 2017

\section{Pemberian Kredit Dan Pencairan Kredit}

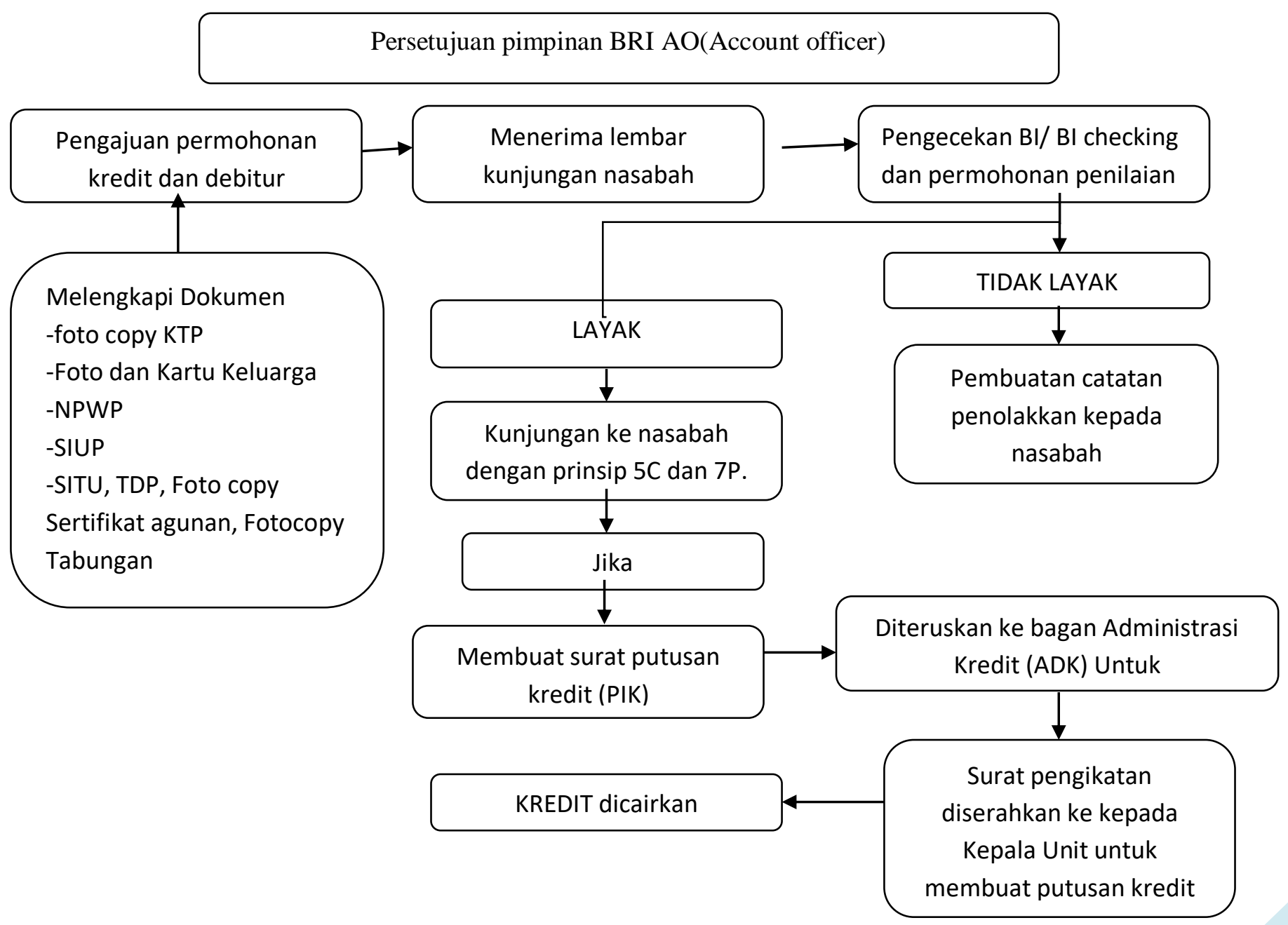

Sumber: PT. Bank Rakyat Indonesia (Persero) Tbk. Cabang Muara Enim Unit Rambang dangku 2017 
H. Pembahasan

1) Penerapan SIA Pada Prosedur Pengajuan, Persetujuan Kredit, dan Pemberian Kredit

\section{a. Penerapan SIA Pada Prosedur Pengajuan Dan Persetujuan Kredit}

Sistem informasi akuntansi (SIA) Sebagai alat bantu untuk mempermudah pimpinan dan dimanfaatkan oleh manajemen dalam pengambilan keputusan. Selain itu, informasi yang dihasilkan adalah informasi yang tepat waktu, relevan, dan dapat dipercaya juga meningkatkan pengendalian yang ada.

Penerapan sistem informasi akuntansi(SIA) dalam kebijakan pemberian kredit PT.Bank Rakyat Indonesia (Persero) Cabang Muara Enim Unit Rambang Dangku sudah berjalan cukup baik, terutama dalam proses pengajuan dan persetujuan kredit. Selain itu sistem informasi akuntansi yang diberlakukan PT.Bank Rakyat Indonesia (Persero) Cabang Muara Enim Unit Rambang Dangku sesuai dengan karekteristik dan unsur-unsur sistem informasi akuntansi (SIA). Dengan adanya SIA maka sistem dan prosedur pemberian kredit diproses dengan jelas mulai tahap pemberian kredit dengan kehati-hatian PT. Bank Rakyat Indonesia (Persero) Cabang Muara Enim Unit Rambang Dangku juga menerapkan prinsip-prinsip 5C terhadap calon debitur, terlihat pada saat proses analisis dokumen atau penyidikan terhadap calon debitur.selain itu SIA juga dapat menunjang perusahaan dalam mematuhi undang-undang dan kebijakan yang telah ditetapkan karena sistem dan prosedur yang benar dan tepat serta sesuai dengan kebijakan dan undang-undang maka didalam proses mendapatkan informasi yang handal. Dan juga bank menerapkan SIA yang memadai yang dimana didalamnya mengandung unsur-unsur dan karakteristik SIA yang digunakan pihak bank khususnya bagian kredit dalam menjalankan kebijakan pemberian kredit.

\section{b. Penerapan SIA Pada Prosedur Pemberian Kredit}

Dalam prosedur pemberian kredit terutama pada sistem pengajuan dan persetujuan kredit untuk debitur. PT.Bank Rakyat Indonesia (Persero) Cabang Muara Enim Unit Rambang Dangku telah menerapakan prosedur tersebut dengan sangat baik terlihat pada hasil penelitian, sebagai berikut :

a. Permohonan Kredit

- Mencari nasabah yang memerlukan dan

- Melakukan survey internal kepada nasabah

- Membuat formulir APPR (Aplikasi pengajuan dan pembukaan rekening

- Melengkapi appr yang belum lengkap oleh nasabah

- Diinput kesistem data nasabah ya sudah benar

b. Penyidikan/ pengecekan dan analisis kredit

- Membuka APPR yang telah diisi

- Memeriksa ulang APPR.

- Melakukan penginputan,BI cheking, UMK cheking, analisa 5C dan 7P

- Memeriksa APPR apakah Tidak Lengkap / Lengkap

- Cek kembali kelengkapan APPR dengan teliti

- Dilakukan penginputan selanjutnya 
c. Keputusan atas permohonan atas debitur

- Keputusan permohonan kredit menurut teori tindakan pejabat dalam menyetujui atau menolak permohonan kredit yang berdasarkan wewenangnya dengan landasan penelitian syarat-syarat umum dan laporan pemeriksaan dan analisis kredit. Sedangkan PT.Bank Rakyat Indonesia (Persero) Cabang Muara Enim Unit Rambang Dangku dalam melakukan keputusan, pimpinan, berwenang memutuskan atas permohonan kredit calon debitur, pimpinan kredit memutuskan persetujuan kredit apabila berkas dan dokumen yang diajuhkan calon debitur telah selesai di analisis dan diperiksa kelengkapannya oleh bagian kredit. Jika persyaratannya lengkap dan sesuai dengan persyaratan yang telah ditentukan oleh PT.Bank Rakyat Indonesia (Persero) Cabang Muara Enim Unit Rambang Dangku, maka permohonannya akan disetujui.

d. Pencairan Kredit

- Persetujuan pimpinan BRI AO (Account Officer)

- Pengajuan permohonan kredit dan debitur

- Kelengkpan dokumen

- Menerima lembar kunjungan nasabah

- Pengecekan BI /BI Cheking dan permohonan penilaian

- Layak

- Kunjungan ke nasabah dengan prinsip 5C dan 7P

- Jika membuat surat putusan kredit (PIK)

- Diteruskan ke bagan Administrasi Kredit (ADK)

- Surat pengikatan diserahkan kepada kepalah Unit untuk membuat putusan kredit (PIK)

- Kredit dicairkan

- Tidak layak

- Pembuatan catatan penolakan kepada nasabah.

e. Pelunasan Kredit

PT.Bank Rakyat Indonesia (Persero) Cabang Muara Enim Unit Rambang Dangku pelunasan kredit tahap akhir dilakukan dengan baik disertai dengang penyerahan jaminan dan tanda terima jaminan yang ditandatangani oleh debitur sebagai tanda kredit telah lunas dan jaminan telah diserahkan pada debitur.

\section{c. Penerapan Sistem Informasi Akuntansi (SIA) Dalam Pemberian Kredit}

Penerapan Sistem Informasi Akuntansi (SIA) dalam pemberian kredit telah memadai jika didalamnya terkandung Karakteristik dan Unsur-unsur SIA itu sendiri. Penulis melakukan penelitian terhadap Sistem Informasi Akuntansi (SIA) berdasarkan Karakteristik dan unsur-unsur SIA yaitu: usefulness, economy, reability, customer service, capacity, simplicity, flexibelity dan unsur-unsur Sistem Informasi Akuntansi (SIA) tersebut terdapat manusia, alat, catatan, data, dan laporan. Demikian halnya dengan Sistem Informasi Akuntansi (SIA) yang ada di PT. Bank Rakyat Indonesia (Persero) Cabang Muara Enim Unit Rambang Dangku yang menerapkan Karakteristik dan unsur-unsur Sistem Informasi Akuntansi (SIA).

Sistem Informasi Akuntansi (SIA) dalam pemberian kredit terutama pada sistem pengajuan dan persetujuan kredit PT. Bank BRI (Persero) Cabang Muara Enim Unit Rambang Dangku telah memadai dan berjalan baik karena telah terdapat karakteristik dan unsur-unsur SIA sehingga menghasilkan informasi yang berguna dan dibutuhkan oleh bagian kredit. 
Pelaksanaan analisis pemberian kredit PT.Bank BRI (Persero) Cabang Muara Enim Unit Rambang Dangku telah dilakukan dengan baik, dengan menggunakan prinsip kehati-hatian 5C (character, capacity, capital, collecteral, dan condition) dan 7P ( personality, party, purpose, prospect, payment, profitability, and protection) tersebut dilakukan dengan melihat dokumen-dokumen yang diajuhkan oleh debitur ,wawancara, peninjauan ke lokasi, dan bank melakukan BI cheking. Sehingga membantu dalam menghasilkan keputusan mengenai layak tidaknya seorang debitur dalam memperoleh kredit.

Secara keseluruhan sistem pemberian kredit yang dilakukan PT.Bank BRI (Persero) Cabang Muara Enim Unit Rambang Dangku sudah sesuai dengan stuktur dan sangat baik, namun ada sedikit kelemahan dari kebijakan sistem prosedur pengajuan dan persetujuan kredit yang terjadi dilapangan seperti kecurangan dengan manipulasi data dan kolusi antara bagian kredit Bank dengan pihak nasabah tersebut.

\section{Kesimpulan}

Berdasarkan hasil penelitian dan pembahasan, bahwa SIA atas prosedur pemberian kredit khususnya sistem pengajuan dan persetujuan kredit, dapat disimpulkan sebagai berikut:

1) Penerapan SIA pemberian kredit yang dilaksanakan oleh PT. Bank Rakyat Indonesia (Persero) Tbk Cabang Muara Enim Unit Rambang Dangku sudah menerapkan Karakteristik dan unsur-unsur sistem informasi akuntansi dengan baik dan dapat menghasilkan informasi yang berguna bagi pihak perkreditan PT. Bank Rakyat Indonesia (Persero) Tbk Cabang Muara Enim Unit Rambang Dangku.

2) Prosedur pemberian kredit yang dilaksanakan PT. Bank Rakyat Indonesia (Persero) Tbk Cabang Muara Enim Unit Rambang Dangku sudah menerapkan Prinsip 5C dan 7P dengan cukup baik dan terstruktur. Prosedur pengajuan dan persetujuan kredit tersebut merupakan prosedur pemberian kredit yang dilakukan oleh PT. Bank Rakyat Indonesia (Persero) Tbk Cabang Muara Enim Unit Rambang Dangku pada umumnya dalam memberikan kredit, dan sesuai langkah-langkah yang ditetapkan Bl.

3) Penerapan SIA pemberian kredit telah memadai dan sudah sesuai dengan teori-teori yang relevan dengan masalah yang dianalisis.

\section{J. Saran}

1) Sebaiknya secara berkesinabungan pihak manajemen perlu mengontrol SIA yang telah dijalankan. Disamping itu perlu adanya pengembangan SIA dan SDM yang kompeten untuk memenuhi kebutuhan pasar yang selalu berkembang seiring dengan perkembangan IPTEK.

2) Sebaiknya perlu ditinjau ulang kebijakan kredit dalam setiap prosedurnya agar tidak terjadi kecurangan-kecurangan antara bagian kredit bank dengan pihak nasabah.

3) Sebaiknya Penerapan sistem informasi akuntansi(SIA) harus selalu diterapkan sehingga kegiatan bank sejalan dengan hukum dan peraturan yang berlaku. 


\section{DAFTAR PUSTAKA}

Diana, anastasia\& setiawati, lilis. 2010. sistem informasi akuntansi. yogyakarta: penerbit CV ANDI OFFSET.

Febrianty. 2009. Evaluasi penerapan sistem informasi akuntansi terhadap sistem pengajuan dan persetujuan kredit pada PT BPR, jurnal akuntansi. Universitas Gunadarma.

Guraso, Avian. 2012. Analisis sistem informasi akuntansi dan pengendalian internal pada PT BTN MUR( Mitra Usaha Rakyat) TBK. Jurnal Akuntansi : Jakarta.

Hall, james A.2011. sistem informasi akuntansi edisi. Jakarta : Penerbit Salemba Empat

Jogiyanto.2009. sistem teknologiinformasi.yogyakarta:CV ANDI OFFSET.

Kasmir. 2014. Dasar-dasar perbankan edisi revisi 2014. Jakarta: penerbit PT Raja Grafindo Persada

Krismaji. 2010. Sistem Informasi Akuntansi Edisi Ketiga. Yogyakarta : penerbit UNIT PENERBIT DAN PERCETEKAN SEKOLAH TINGGI ILMU MANAJEMEN.

Mardi, 2011. Sistem Informasi Akuntansi. Jakarta : penerbit salemba empat

Pasolang, ronald. 2013. evaluasi sistem pemberian kredit (Studi Kasus Pada Bank BPR Hidup Arthagraha, Muntilan). skripsi akuntansi. UNIVERSITAS SANATA DHARMA YOGYAKARTA.

Pedoman Penulisan Skripsi Tahun Akademik 2017/2018. Fakultas Ekonomi

Universitas Persatuan Guru Republik Indonesia Palembang.

Romney, M.B.\& Steimbart, P.J. 2015. Sistem Informasi Akuntansi edisi 13. jakarta selatan : penerbit salemba empat.

Sadeli, Lili M. 2011. DASAR-DASAR AKUNTANSI. PT BUMI AKSARA.

Sasongko, Catur, dkk. 2016. AKUNTANSI SUATU PENGANTAR (BERBASIS PSAK). Jakarta Selatan: SALEMBA EMPAT

Sedarmayati \& Hidayat, syarifudin. 2011. metodologi penelitian. Bandung : penerbit CV. Mandar Maju.

Sugiarto. 2013. Credit Management Handbook (Manajemen Perkreditan Cara Mudah Menganalisis Kredit). Jakarta: PT Raja Grafindo Parsada.

Sugiyono. 2017. metode penelitian kuantitatif, kualitatif, dan R\&D. Bandung: ALFABETA

Sujarweni, V.Wirana. 2015. Metodeologi Penelitian Bisnis dan Ekonomi. Yogyakarta: Penerbit Pustaka Barupres

Susanto, A. (2008), Sistem Informasi Akuntansi. Bandung : Penerbit Lingga Jaya 